\title{
The Informativeness Of Cash Flow Forecasts And The Regulation FD Environment
}

Karin A. Petruska, Youngstown State University, USA

\begin{abstract}
Prior literature shows that analysts' forecast estimates serve as a proxy for the markets' and investors' beliefs which are unobservable. For decades, analysts have generated forecasts for use in valuation models including future estimates of earnings and growth. Yet, only recently, analysts have begun to voluntarily provide cash flow per share forecasts at the same time they are producing earnings per share forecasts for firms they follow. This study addresses whether the tendency of analysts to issue cash flow per share forecasts, as a result of changes in the regulatory environment, affects forecast properties. By examining the time frame surrounding Regulation $F D$, the analysis provides evidence that both the mere existence and the relative measure of analysts' cash flow per share forecasts differ in explaining analysts' earnings forecast accuracy. Specifically, the empirical results demonstrate that the relative value of analysts' cash flow forecasts, the implied value of unexpected accruals, and cash flow forecast errors facilitate the reduction in analysts' earnings forecast errors subsequent to the passage of Regulation FD. Further, the inverse relation between these analysts' inputs and earnings forecast errors appear to be driven by firms with more accurate cash flow forecasts.
\end{abstract}

Keywords: cash flow forecasts; earnings forecasts; forecast error; Regulation FD

\section{INTRODUCTION}

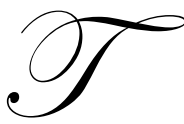

here has been a significant amount of research conducted which investigates analysts' earnings forecasts and their economic consequences (Abarbanell and Lehavy 2003; Ali et al. 1992; Cohen and Lys 2003; Kasznik and McNichols 2002). Analysts' earnings forecasts provide expectations of a firm's future prospects that play a role in firm valuation (Kasznik and McNichols 2002). More accurate forecasts are predicted to produce more accurate valuations. Ultimately, earnings expectations are predicted to be linked to both price and volume reactions when firms announce earnings (Abarbanell et al. 1995). However, if there are limitations and inefficiencies in analyst information processing, and the capital markets do not draw from appropriate sources, then prices may not fully reflect financial data (Beaver 2002).

Recently, analysts have begun generating cash flow per share forecasts for firms, based on estimates of net cash flow from operations, at the same time they are forecasting earnings per share estimates. Givoly et al. (2009) state that cash flow forecasts have increased in frequency over the last decade from 2.5 percent in 1993 to 57.2 percent in 2005. In spite of this increasing trend, it is still unclear what incentivizes analysts to provide these forecasts. Limited research has been conducted in this area, most presumably because these forecasts represent a relatively new measure. Some of the earliest research in the area has been based on the investor demand hypothesis. DeFond and Hung (2003) state that investors demand and analysts supply cash flow forecasts for firms with low quality earnings. As such, they find that firms with large accruals, less homogeneous accounting choices, high earnings volatility, high capital intensity, and poor financial strength are more inclined to have analysts disseminate cash flow forecasts. Likewise, in a similar international study, DeFond and Hung (2007) find that analysts generate cash flow forecasts for firms with poor anti-director rights and weak legal enforcement. 
While these prior studies have focused on the forecasting behavior of sell-side financial analysts, Wasley and $\mathrm{Wu}$ (2006) show that management of firms also recently began to voluntarily disclose their cash flow forecasts. They find that management issues cash flow forecasts to signal good news relating to future cash flow prospects. This disclosure enables management to meet investors' demands for cash flow information and to show that the composition of earnings consists of a higher level of cash versus accruals. Thus, management believes that cash flow information provides investors with an indication that earnings management is mitigated in the organization.

Although these prior studies examine firm-level financial characteristics shown to increase the potential for investor demand and, subsequently, analysts' supply of cash flow information, studies have not directly tested the effects of regulation on the increasing trend of cash flow forecasts over time. Wasley and $\mathrm{Wu}$ (2006) speculate that one of the potential reasons for the increase in the issuance of management cash flow forecasts could be partly due to Regulation Fair Disclosure (hereafter, Reg FD). They report that the monthly frequency of management cash flow forecasts experienced a sharp increase in 2001 and 2002. However, they did not formally test the role of regulation and its effect on analysts' forecasting abilities. Thus, this current study fills a void in the literature by empirically examining if government regulation plays a role in the propensity of sell-side analysts to issue these supplemental cash flow disclosures. Further, this study contributes to the literature by documenting how earnings forecast accuracy can vary based on the mere existence, the relative measure, and the accuracy of analysts' cash flow forecasts.

Regulation FD provides a natural setting to test for changes in the behavior of analysts' forecasting skills. Barniv et al. (2009) show that government regulations such as Reg FD help to better explain analyst behavior patterns in terms of mitigating the attenuation between analysts' stock recommendations and both residual income estimates and valuation heuristics, respectively. In August, 2000, the Securities and Exchange Commission issued Regulation Fair Disclosure Rule as part of the Selective Disclosure and Insider Trading Regulation. This ruling which targets security analysts states, "When an issuer or persons acting on its [the firm's] behalf, disclose material, nonpublic information to certain enumerated persons, it must make public disclosure of that information by filing Form 8-K or through another comparable and widely distributed medium"(SEC 2001). Reg FD has been found to be effective at curtailing selective disclosure as evidenced by the findings that show analyst forecast dispersion and bias and low levels of analyst following are positively correlated with Reg FD (Bushee et al. 2004; Shane et al. 2001). This relation implies that during the Reg FD period, analysts had more difficulty in formulating forecasts because information was not selectively being provided to them by management (Irani and Karamanou 2003) and the absolute price-discovery impact of information generated by financial analysts was lower by $28 \%$ (Gintschela and Markov 2004). Overall, Reg FD "leveled the playing field" for investors and analysts. As a result, after this rule was enacted, researchers found that analysts were less accurate in their earnings forecasts and forecasting skills decreased (Aggarwal et al. 2005; Shane et al. 2001; Irani and Karamanou 2003; Gintschela and Markov 2004). Forecast errors are important to analyze because they are used to understand the properties of analysts' information environments (Barron et al. 1998). However, whether the information contained in analysts' cash flow forecasts is able to attenuate information asymmetry and reduce the difficulty in formulating earnings forecasts in the post-Reg FD period remains an empirical question.

While prior research provides evidence on incentives to study cash flow forecasts, Givoly et al. (2009) note several deviations in their quality compared to earnings forecasts. They attribute these differences in part to accuracy, bias, efficiency, and benchmarking. On one hand, they state that cash flow forecasts exhibit a short history, which predisposes the forecasts to a longer learning curve, more limited availability, and less preannouncement management guidance than earnings forecasts. On the other hand, related to Brown et al. (1987), they find that analysts' cash flow forecasts are more accurate than earnings forecasts based on a time series prediction model that regresses future cash flows on prior year's net operating cash flows and changes in working capital accruals. Call et al. (2009) demonstrate that earnings forecasts are more accurate for firms for which analysts' simultaneously issue cash flow forecasts. This increased accuracy can be attributed to the ability to gain a more coherent perspective of a firm's earnings process by generating a complete set of financial statements.

This current study is also motivated by the increased focus and attention given to cash flows at a time when earnings management is taking place. If analysts' forecasts serve as a proxy for investors' beliefs, and investors believe that earnings have the potential to be manipulated, then the inclusion of cash flow forecasts by analysts may 
decrease this bias. Burgstahler and Eames (2003) reveal that analysts are fixated on earnings despite managers' attempts to avoid losses or decreased earnings. Sloan (1996) states that investors underestimate the persistence of cash flows and overstate the persistence of accruals, leading to what is termed the accrual anomaly by fixating on the earnings component. McInnis and Collins (2011) find that earnings quality improves because cash flow forecasts implicitly provide a forecast of unexpected accruals. Call et al. (2009) provide evidence that, for firms for which analysts generate cash flow forecasts, analysts are able to correct for the underestimation of the cash and accrual components, thus reducing mispricing by as much as 30 percent.

This study contributes to the existing literature in several ways. First, it validates prior research which provides evidence that analysts' earnings forecast errors are positive and significantly higher in the post-Reg FD period due to deterioration in report informativeness (Francis et al. 2006). As a natural extension to the prior research conducted on Reg FD, the analysis specifically addresses whether a difference occurs between 1.) the mere existence or 2.) the relative measure of analysts' cash flow forecasts and the corresponding reduction in analysts' earnings forecast errors in the post-regulation period while also controlling for variables known to influence earnings forecast errors including size, profitability, volatility, and growth. I also examine whether the dissemination of these cash flow forecasts provides intrinsic unexpected accrual information capable of lowering forecast errors and whether analysts' cash flow forecast errors improve analyst learning and forecasting skills. In sensitivity tests, I follow the suggestions in Givoly et al. (2009) by examining whether the results are driven by firms characterized by more accurate cash flow forecasts.

The findings indicate that for firms for which analysts issue both earnings and cash flow forecasts, the mere existence of a cash flow forecast is not associated with mitigated forecast errors. However, for firms with cash flow forecasts, the relative measure or value of the forecast does provide supplemental information that attenuates earnings forecast error. These results have implications for disclosure research as, it is not merely the indication of disclosure that can affect transparency, but the quality of the report informativeness. Next, the value of the implied unexpected accruals that are defined as the difference between analysts' earnings forecasts and cash flow forecasts are shown to be associated with lower forecast error. This finding suggests that the intrinsic information in unexpected accruals, which results from forecasting a complete set of financial statements, contains additional information content which facilitates a reduction in earnings forecast errors. Overall, this study contends that while analysts' cash flow forecasts should not be used as a substitute for earnings expectations, the accompaniment of these cash flow forecasts in firm valuation could provide substantive benefits.

The remainder of this paper is organized as follows. Section 2 reviews the relevant literature and hypotheses development. Section 3 presents the research design and model development. The data sources and sample selection process are discussed in Section 4. Section 5 presents the empirical results. Section 6 presents additional sensitivity tests. Lastly, Section 7 summarizes the results and conclusions.

\section{LITERATURE REVIEW AND HYPOTHESES DEVELOPMENT}

An extensive amount of research has been conducted on financial sell-side analysts' research productivity and forecasting skills. Forecast performance plays a critical role in establishing analysts' reputations (Jacob et al. 1999) and analysts' behavior patterns (Clement 1999). Analysts are motivated to provide accurate forecasts in order to increase compensation levels and career prospects, brokerage house and investment banking business, and firm market value. Pope (2003) notes that an important determinant of the quality of analysts' forecasts is the disclosure level that influences forecast accuracy. Likewise, Schipper (1991) contends that analysts have an incentive to meet investors' demands for value-relevant information. Investors and analysts are able to predict earnings more accurately using this available information. Therefore, the reliability or quality of accounting information will be more fundamental in improving analysts' forecast performance when the disclosure level is high and contains greater information content.

However, analysts need access to managements' proprietary information in order to improve their forecast precision. For example, analysts contribute greater effort in following firms with intangible assets and whose value is less well-captured by accounting applications (Barth et al. 2001). Prior to Reg FD, analysts were privy to confidential information supplied by management that was not ordinarily disseminated to the public. In order to 
remain on favorable terms with management to ensure obtaining this private information, analysts optimistically biased forecasts and "walked down" estimates closer to the earnings announcement date (Richardson et al. 2004). Both Lim (2001) and Das et al. (1998) present empirical evidence that reveals that, in general, analysts' earnings forecasts are more optimistically biased when earnings are less predictable and when the forecast task is more complex. However, Eames and Glover (2003) find no evidence of biased forecasts after controlling for the level of earnings. Mikhail et al. (2003) shows that more experienced analysts tend to issue more pessimistic forecasts rather than optimistic forecasts. In other words, analysts tend to underreact to prior earnings surprises less as they gain more firm-specific experience.

Since research has indicated that most analysts' forecasts are optimistic, there could be an inherent bias related to the underwriting of the firm's securities issue. Analysts' forecast errors have also been shown to be serially correlated and underestimate the persistence of earnings (Ali et al. 1992; Abarbanell and Bernard 1992). However, analysts' earnings forecasts do not reflect all information. Cross-sectional determinants of analysts' forecast revisions and whether the informativeness of analysts' reports is due to the markets' over or underreaction to analysts' reports is studied in Frankel et al. (2006). Investors are shown to place decreasing weights on their prior beliefs and increasing weights on the accuracy of the forecast record (Chen et al. 2005). Investors' reactions to forecast news are also found to be increasing in the product of the accuracy and length of the analyst forecast record.

Due to the many corporate accounting scandals that have taken place, the financial press and investors have frequently expressed suspicions about the economic justification of earnings based on accrual accounting and have suggested the use of cash flows to help validate the information in earnings (Garrod and Hadi 1998). However, cash flow per share and cash flow per share forecasts are not a required component of GAAP financial statements (McEnroe 1996). Penman (2004) suggests that investors and financial intermediaries find cash flows useful in evaluating earnings quality and in gauging whether earnings are likely to contain misstatements. Prior research finds that past earnings forecasts may be an incomplete signal of future results (Abarbanell 1991). Earnings can include managers' biased estimates of future firm actions which can inherently be more susceptible to manipulation than cash flows. Certain accruals that encompass earnings may have transitory components that do not persist in the future (Allen and Cote 2005). Cash flows have been found to be the permanent component of earnings and have greater persistence than accruals in estimating future cash flows. Ali et al. (1992), Sloan (1996), and Barth et al. (2001) indicate that the cash flow component is the stronger indicator of future firm performance.

Conversely, Dechow et al. (1998) model earnings, cash flows, and accruals and note that their findings imply that, depending on the operating cash cycle, earnings are a better predictor of operating cash flows than current operating cash flows. Black (1998) also notes that earnings have been found to be more value relevant than operating, investing, or financing cash flows in mature life-cycle stages. However, Barth et al. (2001) extends this framework and finds aggregate operating cash flows and accrual components have significant predictive ability for future operating cash flows. As such, she argues that cash flow prediction is fundamental to assessing firm value.

The relevance of using cash flow forecasts deals with the notion that accounting consists of both historical costs and accrual-based accounting estimates. It is often acknowledged that cash flow measures may be harder to manipulate than the earnings component and may provide incremental value. Not only does cash flow measure how efficiently cash is used, but it can serve as a deciding factor in whether to pursue a merger, extend operations globally, or introduce a new product line (Gamble 2005). Therefore, a general expansion of economic activity has elevated the need for cash flow transparency. An increase in merger and acquisition activity and compliance requirements due to the Sarbanes-Oxley Act (SOX) have also required firms to be more cognizant of their future cash flow positions. While there has been limited research conducted which examines capital market theory relating to analysts' cash flow forecasts, DeFond and Hung (2003) examine the association between stock returns and cash flows. Stock return distributions centered on the earnings announcement date for firms with cash flow forecasts are positively related to cash flow forecast errors, but not earnings forecast errors. This finding suggests that investors demand cash flow forecasts when earnings are perceived as less useful in securities valuation.

Opponents of Reg FD have argued that this rule would have a negative effect on earnings forecasts by decreasing the quantity and quality of publicly available information. According to prior research, the job of predicting earnings has become harder under the passage of Reg FD because the rules do not permit companies to 
make private disclosures to analysts without a corresponding public announcement, conference call, or press release. Research has shown that following the post-Reg FD period, there is a decrease in analyst forecast quality as evidenced by a decrease in analyst following and an increase in forecast dispersion (Irani and Karamanou, 2003). This effect is significantly larger for early forecasts rather than for later forecasts and for smaller companies than for larger companies (Agrawal et al. 2006). Moreover, analysts with high unexplained levels of forecast accuracy are not able to sustain these levels in the post-Reg FD period (Findlay and Mathew 2006). Accordingly, if Reg FD is successful at curtailing selective disclosure, it would be expected that there would be a positive relation between the post-Regulation FD period and analysts' earnings forecast errors as the forecasting task becomes more complicated and the guesswork grows.

Conversely, although Reg FD has reduced the discussions between managers and analysts, the percentage of earnings announcements that meet or beat analysts' expectations has not decreased, and market reactions to earnings announcements are reduced (Shane et al. 2001). Research has also shown that after implementation of Reg $\mathrm{FD}$, the information contained in stock prices prior to earnings announcements were more efficient as evidenced by smaller differences between the pre- and post-announcement stock prices. For example, (Heflin et al. 2003) found mixed or weak evidence in the relation between analyst earnings forecast errors and dispersion during the Reg FD period.

Since capital markets are concerned with future performance levels more so than past performance, analysts' cash flow forecasts may provide additional information content and disclosure in predicting future earnings and increasing forecast accuracy. Healy et al. (1999) demonstrate a negative relation between sustained increases in disclosure and forecast dispersion. However, deterioration in information content could decrease forecast accuracy. Lang and Lundholm (1996) illustrate that low-rated disclosure quality by analysts results in higher forecast dispersion. Barron et al. (1999) find similar evidence with regard to low-rated disclosure quality by the SEC.

Analysts do not always incorporate earnings into their recommendations which are consistent with present value models, but rather, they rely on valuation heuristics. Bradshaw (2004) used analysts' forecast errors as inputs to the residual income valuation model. Yet, the valuations were not able to explain stock recommendations. These findings suggest that analysts use other types of valuation methods. After Reg FD, management of firms were found to issue more voluntary, earnings-related disclosures, which are consistent with firms substituting voluntary, public disclosures to at least partially offset reductions in information flows for analysts. Likewise, according to Mohanram and Sunder (2006), analysts were found to increase the level of information obtained from their own private discovery of idiosyncratic information. Their finding suggests that analysts went to greater lengths to improve their precision of information and to increase the accuracy of their forecasts after the passage of Reg FD. Thus, it remains an empirical question if analysts use cash flow forecasts as an effective means of increasing their forecasting skills in the post-Reg FD environment.

Prior research also indicates that during conference calls, analysts gained privileged knowledge on cash flow projections. Management treated this material information as an attraction in gaining favor with certain analysts. If Reg FD decreases the quality of earnings, analysts may be more inclined to generate cash flow forecasts to compensate for the increase in analysts' forecast errors and the widening of analysts' forecast dispersion in regards to earnings. Overall, it is reasonable to believe that analysts are more apt to generate cash flow forecasts in order to help overcome inefficiencies that may limit earnings' usefulness. It could be expected that cash flow forecasts provide additional disclosure on the quality of firm performance due to managers' attempts to avoid losses or decreased earnings. If cash flows are deemed to provide supplemental earnings information that benefits market participants, then there should be an inverse relation between the Reg FD period and analysts' cash flow forecasts. Call et al. (2009) model cash flow forecasts using an indicator variable that represents the existence of a cash flow forecast. This specification is important to model because only the sheer existence of a cash flow forecast could attract and influence investors regardless of its relative accuracy. Therefore, first I examine the mere existence of a cash flow forecast and test the following hypothesis. All hypotheses which follow are stated in their alternate form.

H1: Analysts' earnings per share forecast errors are attenuated for firms based on the mere existence of cash flow forecasts issued by analysts in the post-Regulation FD period. 
However, Givoly et al. (2009) imply that differences in the signaling value of cash flow forecasts could occur due to not only the mere existence of a cash flow forecast but the relative value of the forecasted measure. Recall that Givoly et al. (2009) question the accuracy of analysts' cash flow forecasts as opposed to the improved accuracy of earnings forecasts, when accompanied by a cash flow forecast, as documented in Call et al. (2009). Givoly et al. (2009) conduct their analysis using the relative cash flow forecast values. The relative value of cash flow forecasts may take into account more qualitative aspects over time and may contain more information content in terms of disclosure. Following this line of reasoning, I test the following hypothesis:

H2: Analysts' earnings per share forecast errors are attenuated for firms based on the relative measurement of cash flow forecasts issued by analysts in the post-Regulation FD period.

Melendez et al. (2009) state that if firms want to manage earnings, they are more likely to manipulate accruals rather than cash flows. The difference between analysts' earnings forecasts and cash flow forecasts automatically provides an intrinsic forecast of unexpected accruals since earnings consist of an accrual and a cash flow component. Call et al. (2009) provide evidence that for firms for which analysts disseminate cash flow forecasts, analysts and investors place more weight on the cash flow component than the accrual component, thus reducing accrual mispricing. Therefore, it is expected that improvements in forecasts of accruals due to assessing cash flow forecasts could provide additional information to analysts in the Post-Reg FD period that can increase forecast accuracy. As such, the following hypothesis is stated in alternate form:

H3: Analysts' earnings per share forecast errors are attenuated for firms based on the information contained in the intrinsic unexpected accruals forecast for firms with cash flow forecasts issued by analysts in the postRegulation FD period.

\section{RESEARCH DESIGN}

As stated, forecast errors (inverse of analyst accuracy and precision) are often a proxy for the magnitude of difficulty in forecasting earnings and are a reflection of analyst aptitude. To empirically test the above hypotheses, I define analyst earnings per share forecast error. For skewed distributions such as earnings, the mean and the median are likely to be different. Gu and $\mathrm{Wu}$ (2003) find that the skewness of earnings distributions affects the bias in means which suggests that analysts may be apparently optimistic. Absolute analysts forecast error is described by the following equation:

$$
A F E_{i t}=\left|\left(A E P S_{i t}-F E P S_{i t}\right)\right| / P_{i t-1}
$$

Where:

$A E P S_{i t}$ is the reported consensus annual earnings per share for firm $i$ for period $t . F E P S_{i t}$ is the median analyst earnings per share forecast for firm $i$ for period $t . P_{i t-1}$ is the price of the stock at the beginning of the fiscal period $t$ for firm $i$.

Irani and Karamanou (2003) and Heflin et al. (2003) among others model the determinants of dispersion in analysts' earnings forecasts and analyst following both before and after the Reg FD environment. Following this methodology, for all firms with analysts' earnings per share forecasts, I regress analyst forecast error on the Reg FD variable along with several exogenous control variables known to be associated with earnings forecast error. Using a pooled, cross-sectional, time series regression model, I assess whether the Reg FD period is associated with higher earnings forecast errors as represented in regression Model (1).

$$
\begin{aligned}
\text { AFE }_{i t}= & \alpha+\beta_{1} \text { FD }_{i t}+\beta_{2} \text { SIZE }_{i t}+\beta_{3} \text { LOSS }_{i t}+\beta_{4} \text { EPSSTD }_{i t}+\beta_{5} \text { RETSTD }_{i t} \\
& +\beta_{6} \text { SURPRISE }_{i t-1}+\beta_{7} \text { GROWTH }_{i t}+\varepsilon_{i t}
\end{aligned}
$$

All of the variables used in the models and equations are defined in Appendix A. 
Next, Model (1) is extended by interacting the Reg FD variable with the existence of a cash flow forecast variable, $C F D_{i t-1}$, at the beginning of the period for all firms with analysts' earnings per share forecasts. Firms for which analysts provide a cash flow forecasts are coded as 1 and 0 for firms followed by analysts without cash flow forecasts. In Model (2) below, it is expected that the variable $F D_{i t}{ }^{*} C F D_{i t-1}$ will be negative, indicating that the mere existence of a cash flow forecast in the post-Reg FD period versus the pre-Reg FD period is associated with attenuated forecast errors.

$$
\begin{aligned}
A F E_{i t}= & \alpha+\beta_{1} \text { DD }_{i t}+\beta_{2} \text { CFD }_{i t-1}+\beta_{3} \text { FD }_{i t} * C F D_{i t-1}+\beta_{4} \text { SIZE }_{i t}+\beta_{5} \text { LOSS }_{i t} \\
& +\beta_{6} \text { EPSSTD }_{i t}+\beta_{7} \text { RETSTD }_{i t}+\beta_{8} \text { SURPRISE }_{i t-1}+\beta_{9} \text { GROWTH }_{i t}+\varepsilon_{i t}
\end{aligned}
$$

Model (3) takes into consideration the Reg FD variable based on the relative measure of the cash flow forecast variable. It is expected that the variable $F D_{i t}{ }^{*} F C P S_{i t-1}$ will be negative also, indicating that the relative value of a cash flow forecast in the post-Reg FD period versus the pre-Reg FD period is associated with attenuated forecast errors. Model (3) is illustrated below.

$$
\begin{aligned}
A F E_{i t} & =\alpha+\beta_{1} F_{i t}+\beta_{2} F_{C P S}+\beta_{3} F_{i t} * F C P S_{i t-1}+\beta_{4} \text { SIZE }_{i t}+\beta_{5} \text { LOSS }_{i t} \\
& +\beta_{6} \text { EPSSTD }_{i t}+\beta_{7} \text { RETSTD }_{i t}+\beta_{8} \text { SURPRISE }_{i t-1}+\beta_{9} \text { GROWTH }_{i t}+\varepsilon_{i t}
\end{aligned}
$$

Lastly, I account for the interaction of the Reg FD variable with the implied forecast of unexpected accruals variable in Model (4). It is expected that the variable $F D_{i t} * A C C F O R C_{i t-1}$ will also be negative, indicating that the implied forecast of unexpected accruals provides additional information content as a result of the generation of cash flow forecasts by analysts which aids in lower forecast errors (e.g., higher forecast accuracy) in the post-Reg FD period versus the pre-Reg FD period. This is modeled below as:

$$
\begin{aligned}
\text { AFE }_{i t}= & \alpha+\beta_{1} \text { FD }_{i t}+\beta_{2} \text { ACCFORC }_{i t}+\beta_{3} \text { FD }_{i t} * \text { ACCFORC }_{i t-1}+\beta_{4} \text { SIZE }_{i t}+\beta_{5} \text { LOSS }_{i t} \\
& +\beta_{6} \text { EPSSTD }_{i t}+\beta_{7} \text { RETSTD }_{i t}+\beta_{8} \text { SURPRISE }_{i t-1}+\beta_{9} \text { GROWTH }_{i t}+\varepsilon_{i t}
\end{aligned}
$$

\section{SAMPLE SELECTION}

Several data sources are used to acquire the information used in the analysis. First, the Institutional Brokers Estimate System (I/B/E/S) U.S. Detail History and Summary files for the period 1993 through 2007 were used to acquire the list of firms having analyst earnings, stock price, common shares outstanding, and cash flow data. Additional data was obtained from the Research Insight Standard \& Poor's COMPUSTAT annual industrial and research files. This time period is chosen because $\mathrm{I} / \mathrm{B} / \mathrm{E} / \mathrm{S}$ first began accumulating data on analysts' cash flow forecasts in 1993. Additionally, the year 2000 for the $F D_{i t}$ variable is excluded from the sample as this year represents the transition period. I delete firms with standard industrial classification codes of 6000-6999 as these represent firms in regulated industries that may be subject to additional reporting requirements. Table 1 provides the descriptive statistics for the variables of interest. The mean analyst earnings per share forecast error, $A F E_{i t}$, is 0.0341. Analyst forecast errors appear to decrease in the post-FD period which exhibit a mean of 0.0297. More cash flow forecasts appear to be generated by analysts in the post-Reg FD period. The mean cash flow indicator variable, $C F D_{i t-I}$ is 0.0565 in the pre-Reg FD period and 0.4812 in the post-Reg FD period. On average, it also appears that earnings surprises and earnings and stock return volatility are increasing in the post-FD period which could also explain analysts' inclinations to estimate cash flow forecasts. Overall, Table 1 indicates significant differences between the variables in the study in the pre- versus post-Reg FD period. 
Table 1

Descriptive Statistics

\begin{tabular}{|c|c|c|c|c|c|c|c|c|}
\hline \multicolumn{9}{|c|}{ Pre-and Post-Reg FD Periods } \\
\hline & \multicolumn{3}{|c|}{$\begin{array}{c}\text { Pre-Reg FD Period } \\
(1994-1999)\end{array}$} & \multicolumn{3}{|c|}{$\begin{array}{c}\text { Post-Reg FD Period } \\
(2001-2007)\end{array}$} & \multicolumn{2}{|c|}{ Difference } \\
\hline Variable & Mean & Median & $\begin{array}{l}\text { Std. } \\
\text { Dev }\end{array}$ & Mean & Median & $\begin{array}{l}\text { Std. } \\
\text { Dev }\end{array}$ & t-stat & Wilcoxon $\mathrm{Z}$ \\
\hline$\overline{A F E_{i t}}$ & $\overline{0.0341}$ & $\overline{0.007}$ & $\overline{0.0745}$ & $\overline{0.0297}$ & $\overline{0.0098}$ & $\overline{0.0859}$ & $\overline{-11.03} * * *$ & $10.0973 * * *$ \\
\hline$C F D_{i t-1}$ & 0.0565 & 0.0000 & 0.2308 & 0.4812 & 0.0000 & 0.4997 & $-89.01 * * *$ & $-75.1143 * * *$ \\
\hline$F C P S_{i t-1}$ & 2.3480 & 1.7900 & 2.5289 & 2.3964 & 2.0500 & 6.5504 & $-1.63^{*}$ & $-2.4268 * * *$ \\
\hline$S I Z E_{i t}$ & 7.2885 & 6.3292 & 1.7296 & 7.9476 & 6.8417 & 1.5940 & $-17.90 * * *$ & $17.7259 * * *$ \\
\hline $\operatorname{LOSS}_{i t}$ & 0.1599 & 0.0000 & 0.3670 & 0.1282 & 0.0000 & 0.3343 & $-15.72 * * *$ & $-15.4569 * * *$ \\
\hline EPSSTD $_{i t}$ & 0.2513 & 0.0400 & 1.3295 & 0.3643 & 0.0500 & 10.7753 & 0.99 & $-15.5007 * * *$ \\
\hline $\operatorname{RETSTD}_{i t}$ & 0.4352 & 0.4491 & 0.1724 & 0.5247 & 0.4640 & 0.3704 & $-2.40 * *$ & $-4.2856 * * *$ \\
\hline SURPRISE $_{i t-1}$ & 0.0272 & 0.0126 & 0.0332 & 0.0365 & 0.0150 & 0.1948 & $-2.73 * * *$ & $-8.0744 * * *$ \\
\hline$G_{R O W T H_{i t}}$ & 0.0007 & 0.0011 & 0.0034 & -0.0101 & 0.0007 & 0.3361 & $3.42 * * *$ & $11.9962 * * *$ \\
\hline
\end{tabular}

$* * *, * * *$ indicates differences in the mean (t-test) and median (Wilcoxon Rank-Sum) tests between the Pre-and Post-Reg FD period at the $0.01,0.05$, and 0.10 levels based on two-tailed tests, respectively.

Table 2 presents the correlation matrix for the variables presented. The Pearson correlation coefficients are reported above the diagonal for firms (post-Reg FD period) and below the diagonal for firms (pre-Reg-FD period). However, in order to control for other mitigating factors that could affect analysts' earnings forecast errors, ordinary least squares regressions were conducted using panel data.

Table 2

Pearson Correlations for the Pre-and Post-Reg FD Period

\begin{tabular}{|c|c|c|c|c|c|c|c|c|c|}
\hline Variable & (1) & (2) & (3) & (4) & (5) & (6) & (7) & (8) & (9) \\
\hline 1. $A F E_{i t}$ & - & -0.071 & 0.002 & -0.341 & 0.492 & 0.140 & 0.131 & 0.187 & 0.007 \\
\hline 2. $C F D_{i t-1}$ & 0.104 & - & -0.001 & 0.211 & -0.097 & -0.045 & -0.037 & -0.025 & 0.028 \\
\hline 3. $F C P S_{i t-1}$ & 0.043 & 0.078 & - & 0.076 & -0.081 & -0.207 & -0.087 & -0.015 & -0.038 \\
\hline 4. $S I Z E_{i t}$ & -0.317 & -0.019 & 0.207 & - & -0.340 & -0.049 & -0.090 & -0.083 & -0.057 \\
\hline 5. $\operatorname{LOSS}_{i t}$ & 0.433 & 0.094 & -0.108 & -0.250 & - & 0.066 & 0.206 & 0.175 & 0.011 \\
\hline 6. EPSSTD $_{i t}$ & 0.032 & -0.024 & -0.181 & -.0907 & 0.166 & - & 0.030 & 0.023 & 0.000 \\
\hline 7. RETSTD $_{i t}$ & 0.312 & 0.089 & -0.199 & -0.286 & 0.322 & 0.103 & - & 0.076 & 0.002 \\
\hline 8. SURPRISE $E_{i t-1}$ & 0.183 & 0.148 & -0.024 & -0.220 & 0.108 & 0.084 & 0.208 & - & 0.005 \\
\hline 9. $G R O W T H_{i t}$ & -0.206 & 0.009 & -0.130 & 0.034 & -0.163 & 0.017 & 0.048 & -0.068 & - \\
\hline
\end{tabular}

Pearson Correlation coefficients are reported above the diagonal for the Pre-Reg FD period and correlations for the Post-Reg FD Period are reported below the line. Amounts in bold are significant at the 0.05 level.

\section{EMPIRICAL RESULTS}

Table 3 presents the results of the relations between analysts' earnings forecast errors and analysts' cash flow forecasts using several different variables to represent the inputs of cash flow forecasts. In column 3, Model (1), analysts' earnings per share forecast errors are regressed on the Reg FD Period, the main variable of interest, and several control variables used in extant research. The adjusted $\mathrm{R}^{2}$ of the model is $27.95 \%$. The coefficient $F D_{i t}$ is positive and significant at the $\alpha=0.01$ level which indicates that Reg FD was successful at selective disclosure. This relation supports prior research that shows analysts have more difficulty in formulating forecasts because information was not being privately provided to them by management (Irani and Karamanou 2003). An increase in forecast errors indicates that analysts are less accurate in predicting earnings because of poorer forecasting skills in the post-Reg FD period compared to the pre-Reg FD period when analysts had closer ties to management and proprietary information. 
In column 4, Model (2), the variable that represents the mere existence of a cash flow forecast in the postReg FD period is $F D_{t} * C F D_{t-1}$. The coefficient is 0.0063 and is not significant. The mere presence of a cash flow forecast is not associated with reduced earnings forecast errors. As a result $\mathrm{H} 1$ is not supported. This finding also has ramifications for future studies that use cash flow forecast indicator variables in their analysis and supports the contentions expressed regarding the quality of analysts' cash flow forecasts by Givoly et al. (2009). Furthermore, this finding suggests that it is not merely the formulation of a cash flow forecast by analysts' in the post-Reg FD period that affects forecast accuracy.

Next, in column 5, we find support for H2, in that Model (3) illustrates that the relative value of the cash flow forecasts generated by analysts is associated with more reduced forecast errors. The variable of interest is $F D_{t}{ }^{*} F C P S_{t-1}$ and the coefficient, -0.0035 , is negative and significant at the 0.05 level. This finding has implications for disclosure in that the discovery of knowledge and research based on idiosyncratic information generated by analysts are transferred to cash flow reports and factors into their forecasting skill set, leading to more accurate earnings forecasts.

Model (4), column 5, is used to determine whether the implied value of forecasted unexpected accruals represents additional information precision that can reduce earnings forecast errors. The variable $F D_{i t}{ }^{*} A C C F C_{t-1}$ has a coefficient of -0.2175 and is negative and significant at the 0.01 level. This relation supports $\mathrm{H} 3$ and shows that analysts' earnings forecast errors are attenuated for firms based on the information contained in this intrinsic unexpected accruals forecasts for firms with cash flow forecasts issued by analysts in the post-Reg FD period. This finding also implies that if cash flow forecasts were merely an extrapolation of current earnings forecasts and changes in working capital accruals, then the slope coefficients would not be significantly different from zero and would not be significantly associated with decreased earnings forecast errors.

\section{ADDITIONAL SENSITIVITY TESTS}

I also consider the effect of the beginning period analysts' cash flow forecast errors on earnings forecast error. Analyst cash flow forecast errors are measured as the difference between actual cash flow per share reported by I/B/E/S and analysts' forecasted cash flow per share. However, consistent with Givoly et al. (2009), I/B/E/S has not consistently provided actual cash flow per share information which results in missing values for many firms. Since actual cash flow values are required to compute cash flow forecast error, following Givoly et al. (2009), I use cash flow from operating activities from COMPUSTAT scaled by the number of common shares outstanding. If common shares outstanding is not available from I/B/E/S, COMPUSTAT values are used. Since cash flow forecasts represent a relatively new measure with a shorter time series history, these forecasts lack the extensive research stream provided by earnings studies. However, cash flow forecast errors may reveal additional information to analysts about the firm that could be used to aid in more accurate earnings forecasts. Thus, it would be expected that there would be a negative relation between analysts' cash flow forecasts and earnings forecasts in the post-Reg FD period. Model (5) in Table 3 illustrates that cash flow forecast errors mitigate analysts' earnings forecast errors. This relation suggests that analysts are able to learn from their cash flow forecasts errors and these inputs aid in helping analysts to forecast better earnings.

Additionally, Givoly et al. (2009) suggest some potential inherent quality limitations regarding the accuracy and bias of analysts' cash flow forecasts compared to earnings forecasts. To account for this likelihood, a variable indicator scheme is used where cash flow forecast errors that fall below the median are categorized as 1 for more accurate forecasts, and those above the median are categorized as 0 for less accurate forecasts. Table 3, Model (6), illustrates the regression based on more accurate forecasts only. The regression model for less accurate forecasts is not illustrated. The coefficient for $F D_{t} * F C P S_{t-1}$ is -0.0041 and is significant at the 0.05 level. This finding indicates that analysts' earnings per share forecast errors are attenuated for firms based on the relative measurement of cash flow forecasts issued by analysts in the post-Reg FD period. However, this result appears to be driven by firms with more accurate cash flow forecasts. 


\begin{tabular}{|c|c|c|c|c|c|c|c|}
\hline \multicolumn{8}{|c|}{$\begin{array}{cc} & \text { Table } 3 \\
\text { Relation Between Analysts' Earnings Forecast Errors And A }\end{array}$} \\
\hline \multicolumn{8}{|c|}{ Dependent variable $=\mathrm{AFE}_{\mathrm{it}}$} \\
\hline Variable & $\begin{array}{c}\text { Pred. } \\
\text { Sign }\end{array}$ & Model (1) & Model (2) & Model (3) & Model (4) & Model (5) & $\operatorname{Model}(6)^{\mathrm{a}}$ \\
\hline Intercept & na & $\begin{array}{l}0.0768 * * * \\
(18.44) \\
\end{array}$ & $\begin{array}{l}0.0839 * * * \\
(19.21)\end{array}$ & $\begin{array}{l}0.0795 * * * \\
(8.74)\end{array}$ & $\begin{array}{l}0.0492 * * * \\
(5.14)\end{array}$ & $\begin{array}{l}0.0532 * * * \\
(5.61)\end{array}$ & $\begin{array}{l}0.1150 * * * \\
(6.49)\end{array}$ \\
\hline$F D_{i t}$ & + & $\begin{array}{l}0.0047 * * * \\
(4.22)\end{array}$ & $\begin{array}{l}-0.0022 \\
(-1.46)\end{array}$ & $\begin{array}{l}0.0127 * * \\
(2.34)\end{array}$ & $\begin{array}{l}0.0191 * * * \\
(4.03)\end{array}$ & $\begin{array}{l}0.0037 \\
(0.92)\end{array}$ & $\begin{array}{l}0.0102 * \\
(1.67)\end{array}$ \\
\hline$C F D_{i t-1}$ & na & & $\begin{array}{l}0.0095 * * * \\
(2.89)\end{array}$ & & & & \\
\hline$F D_{i t}^{*} C F D_{i t-1}$ & - & & $\begin{array}{l}0.0063 \\
(1.67)\end{array}$ & & & & \\
\hline$F C P S_{i t-1}$ & na & & & $\begin{array}{l}0.0045 * * * \\
(2.75)\end{array}$ & & & $\begin{array}{l}0.0045^{* * *} \\
(2.27)\end{array}$ \\
\hline$F D_{i t}{ }^{*} F C P S_{i t-1}$ & - & & & $\begin{array}{l}-0.0035 * * \\
(-2.10)\end{array}$ & & & $\begin{array}{l}-0.0041 * * \\
(-2.07)\end{array}$ \\
\hline$S I Z E_{i t}$ & na & $\begin{array}{l}-0.0093 * * * \\
(-19.19)\end{array}$ & $\begin{array}{l}-0.0105 * * * \\
(-19.68)\end{array}$ & $\begin{array}{l}-0.0105 * * * \\
(-9.56)\end{array}$ & $\begin{array}{l}-0.0074 * * * \\
(-8.47)\end{array}$ & $\begin{array}{l}-0.0068 * * * \\
(-5.99)\end{array}$ & $\begin{array}{l}-0.0152 * * * \\
(-6.36)\end{array}$ \\
\hline $\operatorname{LOSS}_{i t}$ & + & $\begin{array}{l}0.0836^{* * * *} \\
(26.03)\end{array}$ & $\begin{array}{l}0.0838 \text { *** } \\
(26.14)\end{array}$ & $\begin{array}{l}0.0995 \text { *** } \\
(13.63)\end{array}$ & $\begin{array}{l}0.0824 * * * \\
(13.09)\end{array}$ & $\begin{array}{l}0.0731 \\
(10.14) * * *\end{array}$ & $\begin{array}{l}0.0936 \text { *** } \\
(8.81)\end{array}$ \\
\hline EPSSTD $_{i t}$ & + & $\begin{array}{l}0.0004 \\
(1.60)\end{array}$ & $\begin{array}{l}0.0004 \\
(1.59)\end{array}$ & $\begin{array}{l}0.0009 \text { *** } \\
(4.22)\end{array}$ & $\begin{array}{l}0.0009 * * * \\
(2.95)\end{array}$ & $\begin{array}{l}0.0529 * * * \\
(4.71)\end{array}$ & $\begin{array}{l}0.0007 * * * \\
(6.57)\end{array}$ \\
\hline RETSTD $_{i t}$ & + & $\begin{array}{l}0.0052 \\
(1.50)\end{array}$ & $\begin{array}{l}0.0059 * \\
(1.76)\end{array}$ & $\begin{array}{l}0.0077 * \\
(1.86)\end{array}$ & $\begin{array}{l}0.0073 \\
(1.16)\end{array}$ & $\begin{array}{l}0.0017 \\
(0.48)\end{array}$ & $\begin{array}{l}0.008 \\
(0.08)\end{array}$ \\
\hline$S U R P R I S E_{i t-1}$ & + & $\begin{array}{l}0.0516^{* * * *} \\
(3.35)\end{array}$ & $\begin{array}{l}0.0509^{* * * *} \\
(3.32)\end{array}$ & $\begin{array}{l}0.0457 * \\
(1.71)\end{array}$ & $\begin{array}{l}0.0431^{*} \\
(1.73)\end{array}$ & $\begin{array}{l}0.0621 * * \\
(2.09)\end{array}$ & $\begin{array}{l}0.0954 * * * \\
(2.90)\end{array}$ \\
\hline GROWTH $_{i t}$ & - & $\begin{array}{l}-0.0047 * * * \\
(-2.81)\end{array}$ & $\begin{array}{l}-0.0046 * * * \\
(-2.43)\end{array}$ & $\begin{array}{l}-0.0015 \\
(-1.60)\end{array}$ & $\begin{array}{l}-0.0021 * * \\
(-2.32)\end{array}$ & $\begin{array}{l}0.0003 \\
(0.20)\end{array}$ & $\begin{array}{l}-0.0033 * * * \\
(-2.54)\end{array}$ \\
\hline$C F F E_{i t-1}$ & na & & & & & $\begin{array}{l}0.1177 * * * \\
(4.20)\end{array}$ & \\
\hline$F D_{t} * C F F E_{i t-1}$ & - & & & & & $\begin{array}{l}-.0001 * * * \\
(-4.21)\end{array}$ & \\
\hline$A C C F C_{i t-1}$ & na & & & & $\begin{array}{l}0.2317 * * * \\
(3.88)\end{array}$ & & \\
\hline$F D_{t} * A C C F D_{i t-1}$ & - & & & & $\begin{array}{l}-0.2175 * * * \\
(-3.64)\end{array}$ & & \\
\hline Adjusted $R^{2}$ & & 0.2795 & 0.2848 & 0.2964 & 03294 & 0.3862 & 03019 \\
\hline$n$ & & 13,800 & 13,800 & 4,242 & 5,088 & 3,354 & 1,410 \\
\hline Clustered Std. E & & Yes & Yes & Yes & Yes & Yes & Yes \\
\hline
\end{tabular}

t-values are reported below the coefficient.

p-values are based on two-tailed tests.

$* * * * * *$ denotes significance at the $0.01,0.05$, and 0.10 levels, respectively

${ }^{\mathrm{a}}$ Chow F-test statistic is 13.49 and is significant at 0.01 level.

\section{SUMMARY AND CONCLUSION}

Recently, analysts have begun to voluntarily provide cash flow per share forecasts for firms they are following at the same time they are producing earnings per share estimates. While very few studies have investigated the role of analysts' cash flow forecasts, some prior studies have suggested that investors demand additional cash flow information and financial analysts, as information intermediaries, react to this demand by supplementing their earnings forecasts with cash flow forecasts.

This study fills a void in the literature by empirically examining if government regulation plays a role in the inclination of sell-side analysts to issue cash flow forecasts by examining the time frame surrounding Regulation 
Fair Disclosure (Reg FD). Prior research finds that Reg FD is positively associated with the widening of forecast dispersion by barring selective disclosure of information by management to analysts. I investigate whether analysts are more likely to generate cash flow forecasts in order to supplement the reduction in management's private information and the resulting forecasting complexity that arises in the post-Reg FD period in order to help overcome the effects that may hinder their forecasting ability when forming earnings estimates.

The analysis provides evidence that both the mere existence and the relative measure of analysts' cash flow per share forecasts differ in explaining the attenuation of analysts' earnings per share forecast errors. Specifically, the relative value of analysts' cash flow forecasts, the information in intrinsic unexpected accruals, and cash flow forecast errors aid in reducing analysts' earnings forecast errors after Reg FD. Overall, this study contends that while analysts' cash flow forecasts should not be used solely as a substitute for earnings expectations, the inclusion of these cash flow forecasts for firm valuation could provide substantive benefits. Further, due to some inherent quality limitations of analysts' cash flow forecasts due to their relatively short time series history and consensus following, in additional sensitivity tests, I find that the ability of the relative value of analysts' cash flow forecasts to mitigate earnings forecasts errors in the post-Reg FD period appears to be driven by firms with more accurate cash flow forecasts.

The results of this study also have implications for analysts, regulators, academics, and policy-makers in support of more transparent disclosures of cash flow reporting information in the financial statements, especially as analysts' cash flow forecasts gain more prominence and following.

\section{DATA AVAILABILITY}

Data used in the study are from publicly available sources. I gratefully acknowledge the contribution of Thomson Financial for providing analyst forecast data available through the International Brokers Estimate System. This data has been provided as part of a broad academic program to encourage earnings expectations research. This paper is derived from the author's major paper requirement while at Kent State University.

\section{AUTHOR INFORMATION}

Karin A. Petruska, Ph.D., CPA received her Ph.D. in Accounting from Kent State University. She is an Assistant Professor in the Lariccia School of Accounting and Finance, Williamson College of Business Administration, Youngstown State University. Her research projects include accounting conservatism, earnings quality and disclosure, analyst following, and international accounting.

\section{REFERENCES}

1. Abarbanell, J., and V. L. Bernard. 1992. Tests of analysts' overreaction/underreaction to earnings information as an explanation for anomalous stock price behavior. The Journal of Finance 47(3): 11811207.

2. Abarbanell, J.S., and R. Lehavy. 2003. Biased forecasts or biased earnings? The role of reported earnings in explaining apparent bias and over/underreaction in analysts' earnings forecasts. Journal of Accounting and Economics 36(1-3): 105-146.

3. Abarbanell, J.S, W.N. Lanen, and R. E. Verrecchia. 1995. Analysts' forecasts as proxies for investor beliefs in empirical research. Journal of Accounting and Economics 20(1): 31-60.

4. Abarbanell, J.S. 1991. Do analysts' earnings forecasts incorporate information in prior stock price changes? Journal of Accounting and Economics 14(2): 147-165.

5. Agrawal, A., S. Chadha, and M.A. Chen. 2006. Who is afraid of Reg FD? The behavior and performance of sell-side analysts following the SEC's fair disclosure rules. Journal of Business 79(6): 2811-2834.

6. Allen, M. and J. Cote. 2005. Creditor's use of operating cash flows: An experimental study. Journal of Managerial Issues 17(2): 198-211.

7. Ali, A., A. Klein and J. Rosenfeld. 1992. Analysts' use of information about permanent and transitory earnings components in forecasting annual EPS. The Accounting Review 67(1): 183-198. 
8. Barniv, R., O-K. Hope, M.J. Myring, and W.B. Thomas. 2009. Do analysts practice what they preach and should investors listen? Effects of recent regulations. The Accounting Review 84(4): 1015-1039.

9. Barron, O.E., C.O. Kile, and T.B. O'Keefe. 1999. MD\&A quality as measured by the SEC and analysts' earnings forecasts. Contemporary Accounting Research 16(1): 75-109.

10. Barron, O.E., O. Kim, S.C. Lim, and D.E. Stevens. 1998. Using analysts' forecasts to measure properties of analysts' information environment. The Accounting Review 73(4): 421-433.

11. Barth, M.E., D.P. Cram, and K.K. Nelson. 2001. Accruals and the prediction of future cash flows. The Accounting Review 76(1): 27-58.

12. Barth, M.E., R. Kasznik, and M. F. McNichols. 2001. Analyst coverage and intangible assets. Journal of Accounting Research 39(1): 1-34.

13. Beaver, W.H. 2002. Perspectives on recent capital market research. The Accounting Review 77(2): $453-474$.

14. Black, E. 1998. Life-cycle impacts on the incremental value-relevance of earnings and cash flow measures. Journal of Financial Statement Analysis 4(1): 40-56.

15. Bhushan, R. 1989. Firm characteristic and analyst following. Journal of Accounting and Economics 11(23): 255-274.

16. Bradshaw, M.T. 2004. How do analysts use their earnings forecasts in generating stock recommendations? The Accounting Review 79(1): 25-50.

17. Brown, L.D. 2001. A temporal analysis of earnings surprises: Profits vs. losses. Journal of Accounting Research 39(2): 221-241.

18. Brown, L. D., Hagerman, R.L., P.A. Griffin, and M.E. Zmijewski. 1987. Security analyst superiority relative to univariate time-series models in forecasting quarterly earnings. Journal of Accounting and Economics 9(1): 61-87.

19. Burgstahler, D.C., and M.J. Eames. 2003. Earnings management to avoid losses and earnings decrease: Are analysts fooled? Contemporary Accounting Research 20(2): 253-294.

20. Bushee, B.J., D.A. Matsumoto, and G.S. Miller. 2004. Managerial and investor responses to disclosure regulation: The case of Reg FD and conference calls. The Accounting Review 79(3): 617-643.

21. Call, A.C., C. Shuping, and Y.H. Tong. 2009. Are analysts' earnings forecasts more accurate when accompanied by cash flow forecasts? Review of Accounting Studies 14(2-3): 358-391.

22. Chen, Q., J. Francis, and W. Jiang. 2005. Investor learning about analyst predictive ability. Journal of Accounting and Economics 39(1): 3-24.

23. Clement, M. 1999. Analyst forecast accuracy: Do ability, resources, and portfolio complexity matter? Journal of Accounting and Economics 27(3): 285-303.

24. Cohen, D., and T. Lys. 2003. A note on analysts' earnings forecast errors distribution. Journal of Accounting and Economics 36(1-3): 147-164.

25. Das, S., C.B. Levine, and K. Sivaramakrishnan. 1998. Earnings predictability and bias in analysts' earnings forecasts. The Accounting Review 73(2): 277-294.

26. Dechow, P.M. and R.G. Sloan. 1997. Returns to contrarian investment strategies: Tests of naïve expectation hypotheses. Journal of Financial Economics 43(1): 3-27.

27. Dechow, P.M., S.P. Kothari, and R.L.Watts. 1998. The relation between earnings and cash flows. Journal of Accounting and Economics 25(2): 133-168.

28. DeFond, M., and M. Hung. 2003. An empirical analysis of analysts' cash flow forecasts. Journal of Accounting and Economics 35(1): 73-100.

29. DeFond, M., and M. Hung. 2007. Investor protection and analysts' cash flow forecasts around the world. Review of Accounting Studies 12(2-3): 377-419.

30. Eames, M. and S. Glover. 2003. Earnings predictability and the direction of analysts' earnings forecast errors. The Accounting Review 78(3): 707-724.

31. Findlay, S., and P.G. Mathew. 2006. An examination of the differential impact of Regulation FD on analysts' forecast accuracy. The Financial Review 41(1): 9-31.

32. Frankel, R., S.P. Kothari, and J. Weber. 2006. Determinants of the informativeness of analyst research. Journal of Accounting and Economics 41(1-2): 29-54.

33. Francis, J., D. Nanda, and X. Wang. 2006. Re-examining the effects of regulation fair disclosure using foreign listed firms to control for concurrent shocks. Journal of Accounting and Economics 41(3): 271-292.

34. Gamble, R. 2005. I see cash in your future. Treasury and Risk Management 15(3): 24-30. 
35. Garrod, N. and M. Hadi. 1998. Investor response to cash flow information. Journal of Business Finance and Accounting 25(5-6): 613-630.

36. Gintschela, A. and S. Markov. 2004. The effectiveness of Regulation FD. Journal of Accounting and Economics 37(3): 293-314.

37. Gu, Z. and J. Wu. 2003. Earnings skewness and analyst forecast bias. Journal of Accounting and Economics 35(1): 5-29.

38. Healy, P.M., A.P. Hutton, and K.G. Palepu. 1999. Stock performance and intermediation changes surrounding sustained increases in disclosure. Contemporary Accounting Research 16(3): 485-520.

39. Heflin, F., K. R. Subramanyam, and Y. Zhang. 2003. Regulation FD and the financial information environment: Early evidence. The Accounting Review 78(1): 1-37.

40. Irani, A. J. and I. Karamanou. 2003. Regulation fair disclosure, analyst following, and analyst forecast dispersion. Accounting Horizons 17(1): 15-29.

41. Jacob, J., T.Z. Lys, and M.A. Neale. 1999. Expertise in forecasting performance of security analysts. Journal of Accounting and Economics 28(1): 51-82.

42. Kasznik, R. and M. F. McNichols. 2002. Does meeting earnings expectations matter? Evidence from analyst forecast revisions and share prices. Journal of Accounting Research 40(3): 727-759.

43. Lang, M.H., and R.J. Lundholm. 1996. Corporate disclosure policy and analyst behavior. The Accounting Review 71(4): 467-492.

44. Lim, T. 2001. Rationality and analysts' forecast bias. The Journal of Finance 56(1): 369-385.

45. Mikhail, M.B, B.R. Walther, and R.H. Willis. 2003. The effect of experience on security analyst underreaction. Journal of Accounting and Economics 35: 101-116.

46. McEnroe, J. 1996. An examination of attitudes involving cash flow accounting: Implications for the content of cash flow statements. International Journal of Accounting 31(2): 161-174.

47. McInnis, J., and D.W. Collins. 2011. The effect of cash flow forecasts on accruals quality and benchmark beating. Journal of Accounting and Economics 51(3): 219-239.

48. Melendez, K., W.C. Schwartz, M. Trombley. 2009. How does the market value accrual and cash flow surprises? Working paper, Louisiana State University.

49. Mohanram, P.S., and S. Sunder. 2006. How has Regulation FD affected the operations of financial analysts? Contemporary Accounting Research 23(2): 491-525.

50. Penman, S.H. 2004. Financial Statement Analysis and Security Valuation. 2nd Edition, McGraw-Hill Irwin.

51. Pope, P.F. 2003. Discussion of disclosure practices enforcement of accounting standards, and analysts' forecast accuracy: An international study. Journal of Accounting Research 41(2): 273-283.

52. Richardson, S., S.H. Teoh, and P.D. Wysocki. 2004. The walk-down to beatable analyst forecasts: The role of equity issuance and insider trading incentives. Contemporary Accounting Research 21(4): 885-924.

53. Securities and Exchange Commission (SEC). 2001. Special study: Regulation fair disclosure revisited. Available at http://www.sec.gov/news/studies/regfdstudy.htm

54. Shane, P., N. Soderstrom, and S. Yoon. 2001. Earnings and price discovery in the post-Reg. FD information environment: A preliminary analysis. Working Paper, University of Colorado at Boulder.

55. Schipper, K. 1991. Analysts' forecasts. Accounting Horizons 5(4): 105-121.

56. Sloan, R.G. 1996. Do stock prices fully reflect information in accruals and cash flows about future earnings? The Accounting Review 71(3): 289-315.

57. Wasley, C. E., and J. S. Wu. 2005. Why do managers voluntarily issue cash flow forecasts? Journal of Accounting Research 44(2): 389-429. 


\section{Appendix A}

\begin{tabular}{|c|c|c|}
\hline \multicolumn{3}{|r|}{ Definitions Of Variable Measures } \\
\hline$A F E_{i t}$ & $=$ & $\begin{array}{l}\text { Analyst consensus earnings forecast error measured by the absolute value of actual earnings per share less } \\
\text { the median forecasted earnings per share deflated by beginning of the fiscal year price. }\end{array}$ \\
\hline$F D_{i t}$ & $=$ & $\begin{array}{l}\text { Indicator variable that takes the value of } 1 \text { for years after 2001, } 0 \text { for years prior to } 2000 \text {. The year } 2000 \\
\text { is excluded from the analysis since Regulation FD became effective on October } 23,2000 \text {. }\end{array}$ \\
\hline$C F D_{i t-1}$ & $=$ & $\begin{array}{l}\text { Indicator variable that takes the value of } 1 \text { for firms for which analysts had issued a cash flow forecast, } 0 \\
\text { otherwise. This variable represents the mere existence of the generation of a cash flow forecast. }\end{array}$ \\
\hline$F D_{t}^{*} C F D_{i t-1}$ & $=$ & Interaction variable which measures the existence of a cash flow forecast in the Post-Reg FD period. \\
\hline$F C P S_{i t-1}$ & $=$ & Relative value of the consensus cash flow forecast supplied by analysts at the beginning of the period. \\
\hline$F D_{t}^{*} F C P S_{i t-1}$ & $=$ & $\begin{array}{l}\text { Interaction variable which measures the relative value of the consensus cash flow forecast supplied by } \\
\text { analysts in the post-Reg FD period. }\end{array}$ \\
\hline$S I Z E_{i t}$ & $=$ & $\begin{array}{l}\text { Natural logarithm of total assets at the end of the fiscal year. Size is negatively related to optimistic } \\
\text { forecast bias (Abarbanell and Lehavy 2003; Das et al. 1998). Firm size has been used in prior research as } \\
\text { a proxy for the amount of prior information available about a firm. Bhushan (1989) and Lang and } \\
\text { Lundholm (1996) find size to be positively associated with analyst following and analyst forecast } \\
\text { accuracy. }\end{array}$ \\
\hline$L_{O S S}$ & $=$ & $\begin{array}{l}\text { Indicator variable that takes the value of } 1 \text { if the reported earnings per share is negative, } 0 \text { otherwise. } \\
\text { Previous research finds it is difficult to forecast earnings for firms with losses. Brown (2001) find } \\
\text { analysts' earnings forecasts of firms that are experiencing losses are often less accurate due to increased } \\
\text { difficulty of estimating losses stemming from earnings management. }\end{array}$ \\
\hline EPSSTD $_{i t}$ & $=$ & $\begin{array}{l}\text { Standard deviation of actual EPS reported by } \mathrm{I} / \mathrm{B} / \mathrm{E} / \mathrm{S} \text {. Firms with volatile earnings are more prone to } \\
\text { larger forecast errors. }\end{array}$ \\
\hline RETSTD $_{i t}$ & $=$ & $\begin{array}{l}\text { Standard deviation of stock return reported by I/B/E/S. Firms with more volatile stock returns are prone } \\
\text { to larger forecast errors. }\end{array}$ \\
\hline SURPRISE $E_{i t-1}$ & $=$ & $\begin{array}{l}\text { Absolute value of the unexpected earnings surprise measured as the annual change in earnings per share } \\
\text { scaled by beginning of the period price. This is a standardized random walk variable that measures the } \\
\text { variability or surprise in earnings at the beginning of the year. Lang and Lundholm (1996) find that larger } \\
\text { earnings surprises are related to less accurate forecasts. }\end{array}$ \\
\hline $\mathrm{GROWTH}_{i t}$ & $=$ & $\begin{array}{l}\text { Growth measured as the annual percentage changes in sales. Dechow and Sloan (1997) find that forecast } \\
\text { accuracy is biased and related to measures of growth. In regards to Reg FD, Gintschela and Markov } \\
\text { (2004) report that analysts are impacted by the amount of information they receive from growth firms for } \\
\text { which they are privy to more management information. During the post-Reg FD period, analysts tended } \\
\text { to issue more forecasts for growth companies versus value companies. }\end{array}$ \\
\hline$A C C F O R C_{i t-1}$ & $=$ & $\begin{array}{l}\text { I/B/E/S reported earnings per share forecast less the cash flow per share forecast at the beginning of the } \\
\text { year. This measure represents analysts' intrinsic accruals forecast or unexpected accruals. }\end{array}$ \\
\hline$C F F E_{i t-1}$ & $=$ & $\begin{array}{l}\text { Analyst consensus cash flow forecast error measured by the absolute value of the actual cash flow per } \\
\text { share less the median forecasted cash flow per share deflated by beginning of the fiscal year price. } \\
\text { Following Givoly et al. (2009), for firms with missing actual cash flow information form I/B/E/S, net } \\
\text { cash from operating activities scaled by the number of shares of common stock outstanding was used } \\
\text { from COMPUSTAT. }\end{array}$ \\
\hline
\end{tabular}

